\title{
HIV vaccine strategy seeks to woo industry
}

Washington. The US National Institute of Allergy and Infectious Diseases (NIAID) has announced a new strategy for HIV vaccine development aimed at strengthening government-industry collaboration and countering market obstacles that have driven companies from this high-risk field.

For the first time, government scientists will specify in advance the scientific criteria to be met before a potential vaccine proceeds to the next stage of development. This essentially guarantees to companies that they will be able to proceed step-by-step towards licensing if they meet specific requirements.

Anthony Fauci, the director of NIAID, outlined the new plan at a conference on AIDS Vaccine Development held last week at the National Institutes of Health (NIH), of which NIAID is a part.

The plan stresses four points. First, the marriage of fundamental to empirical research, to achieve what Fauci calls a "golden mean" of balance between the two. Second, the development of more and better-defined industry-academic collaboration, without which Fauci said the development of a successful vaccine will be "virtually impossible". Third, the better exploitation of opportunities to speed vac- cine research. Finally, enhanced links between NIAID and public and private organizations in the United States and elsewhere, including the United Nations AIDS Programme, Britain's Medical Research Council and France's Agence Nationale de Recherches sur le SIDA.

Fauci later described it as "critical" that the NIAID, in dealing with industry partners, should agree with such partners in advance the scientific criteria to be met before a vaccine proceeds to the next step towards licensing. Prospective agreement on the criteria - which will be determined on a case-by-case basis - will result in a "level playing field" ensuring that "we don't change the rules of the game midway through", said Fauci.

The announcement pleased vaccine developers. "There will be some level of clarity about how these decisions will be made at the start," says Dino Dina, president of Chrison Biocine, the vaccine division of biotechnology firm Chiron, based in Emeryville, California. "There will not be an open-ended set of goals."

In the past, US government scientists have not used pre-agreed criteria in deciding whether to allow vaccines to proceed to the next step in the multistage process of vaccine development leading from the laboratory to animal testing, and - in theory to eventual large-scale tests in humans.

But the latter have not yet taken place. Some in industry claim that companies have been discouraged by a perceived arbitrariness in federal decision-making, leading to a recent decline in the number of companies involved in vaccine development (see Nature 378, 323; 1995).

Precise criteria to be applied under the new plan have not been established for any potential vaccine. But these could include factors such as the requirement that a minimum percentage of volunteers develop defined levels of neutralizing antibodies or cytotoxic lymphocytes before a vaccine can proceed to the next stage.

Fauci remains optimistic that an effective, safe vaccine can be developed, despite obstacles such as the ability of the virus to mutate rapidly. But he says that it is "inappropriate" for those watching vaccine development to focus solely on achieving immunity to HIV. Researchers may well be able to influence the AIDS epidemic dramatically merely by helping the immune system to fight the virus, thereby lowering its concentration in the blood, he said last week.

Meredith Wadman

\section{Yeltsin promises to pay government's debts to scientists}

Moscow. Boris Yeltsin, the Russian president who is currently engaged in a bitter reelection campaign, has responded to protests from scientists about the continued funding crisis in Russian science by promising to clear the government's debts to researchers by next Sunday (25 February).

Delivering a speech at a ceremony for the state science and technology awards earlier this month, Yeltsin said he was aware of the hardships facing the scientific community and announced that 50 billion rubles (US\$1.05 million) had been allocated to clear unpaid salaries and outstanding laboratory maintenance costs.

Yeltsin added that he was aware of the dwindling prestige of science in Russia, and said that, as a result of urgent measures being taken to redress the situation, scientists would soon feel their plight somewhat eased. "The time will come when scientists from all over the world will be happy to come to work in Russia," he promised.

Finance for Russian science has been reduced 15 -fold since 1990 . But for the past several months, money for science - which now amounts to 0.32 per cent of gross domestic product - has not been released by the government. As a result, institutes of the Academy of Sciences have been unable to pay salaries or electricity and gas bills.

At the same time, it is unclear whether
Yeltsin's promise will be sufficient to end the protests. Last week, prominent members of the academy threatened mass hunger strikes and the picketing of government buildings unless the government allocated 250 billion rubles to settle arrears owed to them. They also observed a 'day of action' in protest at the financial freeze.

Furthermore, many believe that Yeltsin's decision to announce the release of funds

\section{IMAGE UNAVAILABLE FOR COPYRIGHT REASONS}

Yeltsin: claims awareness of hardships.

for scientists, and earlier announcements supporting the need for research, may also be tied to political motives. Russians have been hit hard by economic reforms, and many hanker after the old days when jobs and food - though rationed - were more readily available than they are today.

At a recent meeting of the Russian Secu- rity Council, Yeltsin spoke of the need to maintain Russian technological independence. In a throwback to old Soviet rhetoric, he lamented the "foreign threat to the state, caused by the revealing of our technological secrets" and of "foreign intelligence activity in the field of Russian scientific and technological achievements", language disturbingly similar to that used earlier to criticize the work of foreign-funded scientific bodies.

$\& \quad$ Some observers also see evidence of a resurgence of old Soviet ideas in moves to establish a new and generously statefinanced Russian Academy of Technological Sciences (RATS), aimed at coordinating the efforts of scientists and engineers working in the defence industry.

On 7 February, Oleg Soskovets, the prime minister's first deputy, issued a directive for work to begin on setting up the RATS. Its creation was initially rejected by the Russian Duma just over a year ago (see Nature 372, 208; 1994). But an organizing committee headed by Evgeny Velikhov, vice president of the Russian Academy of Sciences, has now been charged with preparing relevant documents, including a draft decree to be signed by Yeltsin.

The 400 scientists and engineers elected to the new academy will be entitled to lifelong stipends equal to members of the Russian Academy of Sciences.

Carl Levitin 